\title{
SiM
}

\section{Grazing for Fuels Management and Sage Grouse Habitat Maintenance and Recovery}

\section{A Case Study From Squaw Valley Ranch}

\author{
By Erica Freese, Tamzen Stringham, Gregg Simonds, and Eric Sant
}

\section{On the Ground}

- Properly applied grazing management may reduce fire frequency in annual grass-invaded sagebrush communities.

- Grazing can be a cost-effective tool for reducing fire potential and protecting sage grouse habitat from burning.

- Squaw Valley Ranch has been able to reduce fire frequency through preventive practices, which include intensive, appropriate livestock management on private lands.

- Publicly managed lands associated with the ranch have experienced large and frequent fires, a hindrance to improving or maintaining sage grouse habitat.

Keywords: wildfire, livestock, federal land, private land.

Rangelands 35(4):13-17

doi: 10.2111/RANGELANDS-D-13-00008.1

(C) 2013 The Society for Range Management

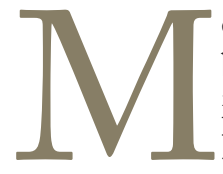

ore than half the total acres (381,727 acres) burned in Nevada during 2012 occurred in sage grouse (Centrocercus urophasianus) Preliminary Priority Habitat (M. Boomer, personal Communication, 2013), an alarming fact for a candidate threatened or endangered species. Preliminary Priority Habitat is defined by the Bureau of Land Management (BLM) as having the highest conservation value to maintaining sustainable sage grouse populations and includes breeding habitat, brood-rearing habitat, winter range, and important movement corridors. Burning sagebrush (Artemisia sp.) communities does not generally benefit sage grouse due to the reduction or elimination of sagebrush cover, ${ }^{1}$ which can take decades to more than a century to recover. ${ }^{2}$ Fires can be particularly detrimental to the quality of sage grouse habitat when invasive annual grasses are present prior to the fire and respond well or expand after fire. Furthermore, it has been suggested that large, frequent fires, like those occurring on Squaw Valley Ranch, may lead to the extinction of sage grouse. ${ }^{3}$ With the continual threat of large fires in sage grouse habitat, it is imperative that cost-effective tools, such as properly managed cattle grazing, are available and utilized to reduce fire frequency, severity, continuity, and size.

\section{Squaw Valley Ranch}

Squaw Valley Ranch, an environmental mitigation property for Barrick Gold of North America, Inc. (Barrick), is located in northern Nevada and like most western US ranches consists of private property and public land grazing allotments. Of the 368,000 acres encompassed by the ranch, Barrick owns 125,000 acres while the rest is mostly under the purview of the BLM; however, some of the private land is intermixed with BLM holdings and managed under the federal grazing permits. The ranch was purchased by Barrick in 1993 to enhance Lahontan cutthroat trout (Oncorbynchus clarki henshawi) habitat and mitigate effects of their mining operations; however, sage grouse and their habitat have become a focal point for ranch managers. Although successful at increasing the numbers and size of Lahontan cutthroat on the ranch between 2003 and 2007 (Trout Unlimited surveys, unpublished data) after improved riparian grazing management, sage grouse lek count numbers have fluctuated with declines occurring after large fire years (e.g., after 2006 and 2012; see Fig. 1).

After leasing the ranch to the prior owners, Barrick took over management in 2002 and hired Open Range Consulting, Inc, to conduct an operations and ranch resource evaluation. From that assessment, several findings came to the forefront: 

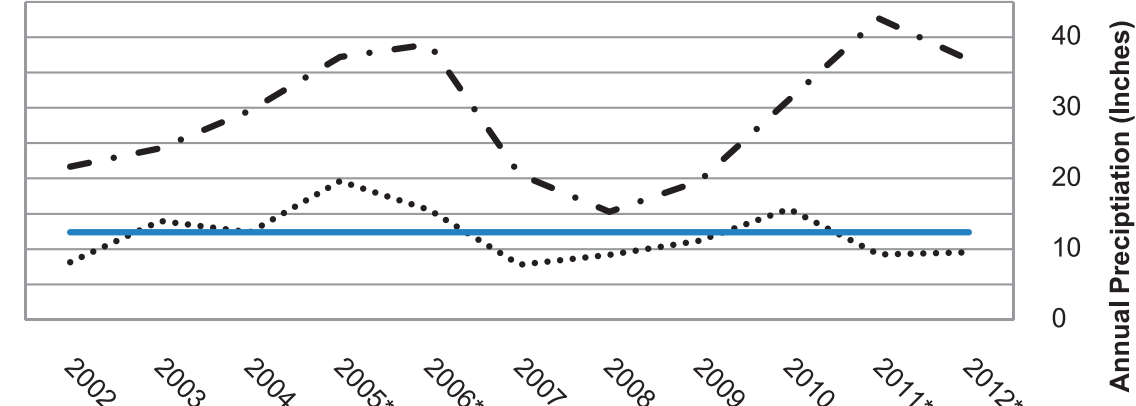

Year

Figure 1. Average number of male sage grouse per lek for 2002-2012, yearly precipitation, and long-term average precipitation for Squaw Valley Ranch. Number of leks counted ranges from two to six, with at least five consistently counted 2004-2012. Note: * indicates years with more than 2,000 acres burned on Squaw Valley Ranch (ranges from 25,000 to over 101,000 acres).

1) rangelands and riparian areas were in poor condition, 2) a change in grazing management could reduce the need for winter feeding of cattle, and 3) substantial capital improvements were needed to fully meet ecological and economic potential. The 2003 ranch evaluation included a land cover assessment, which coupled on-the-ground data collection with satellite imagery to determine current condition and land potential as well as providing a baseline for future improvements and planning. The land cover assessment determined that 1) the upper elevations were dominated by heavy, homogenous sagebrush cover; 2) the middle elevations had converted to cheatgrass after numerous fires; and 3) the lower elevations were dominated by healthy salt-desert shrub communities. Historic continuous (spring through fall) grazing had contributed to the poor rangeland conditions. Therefore, working in cooperation with the BLM, a change in grazing management occurred, which allowed for periods of rest and recovery for the herbaceous community after grazing. The success of the grazing plan relies on flexibility, allowing the ranch to adjust to extreme year-to-year differences in forage production resulting from the Great Basin climate and fire conditions. The grazing plan centers on having enough pastures to manage for rest from grazing within and between years. Over the last decade, the ranch has used timing of grazing, rather than destocking, to improve the rangelands and riparian areas.

\section{Sage Grouse}

In addition to land assessments and grazing management changes, sage grouse lek counts were initiated in 2002 to understand sage grouse dynamics on the ranch in a cooperative effort between Nevada Bighorns Unlimited (NBU), Nevada Department of Wildlife (NDOW), and the ranch. Five leks have been counted every year since 2004. Lek counts are conducted in early spring (March-April), showing response to fires occurring in the previous year. Male sage grouse lek attendance peaked in 2006 and then declined through 2008
(Fig. 1), following big fire years in 2005 and 2006. The burned areas were rested from grazing before (2004-2005) and after (2006-2009) fire. Following rest after fire and subsequent proper grazing management for 3 years, lek attendance peaked again in 2011. In addition to fire, male sage grouse lek attendance appears to be closely associated with annual rainfall (Fig. 1), similar to results reported by Blomberg and colleagues $^{4}$ for male sage grouse recruitment. Lek attendance increased with no grazing until a fire burned the surrounding area, but lek attendance also increased after fire with rest and grazing management centered on timing and utilization of the permitted animal unit months (AUMs). Sage grouse lek attendance does not appear to have been hampered by proper livestock grazing on this ranch.

Recently, sage grouse lek attendance has returned to levels present prior to the large fires of 2005-2006. After each fire, extensive seedings were done on both public and private property due to the proximity of the fires to some of the larger leks on the ranch. The BLM seedings were quite successful and sagebrush has begun to reestablish. On private lands, the ranch worked cooperatively with NDOW and multiple funding entities (Barrick, NDOW, US Fish and Wildlife Service-Partners for Wildlife, and NBU) to implement green-strip seedings around the critical sage grouse habitat. Data gathered from tracking radiocollared hens in the area (NDOW, unpublished data), showed that hens began using the BLM sagebrush seedings for nesting during 2012. Sage grouse population increases have likely been the result of a multifaceted effort that includes proper grazing management, predator control, postfire seeding, and, until 2012, a relative lack of large fires since 2006. Unfortunately, the impacts of the 2012 Willow Fire, which burned most of the remaining intact sagebrush communities on the ranch (over 40,000 acres), are yet to be fully realized. However, the recent use of the BLM seedings by sage grouse may alleviate the impacts from the loss of critical sagebrush habitat during the Willow Fire. Since fire has mostly negative impacts on 


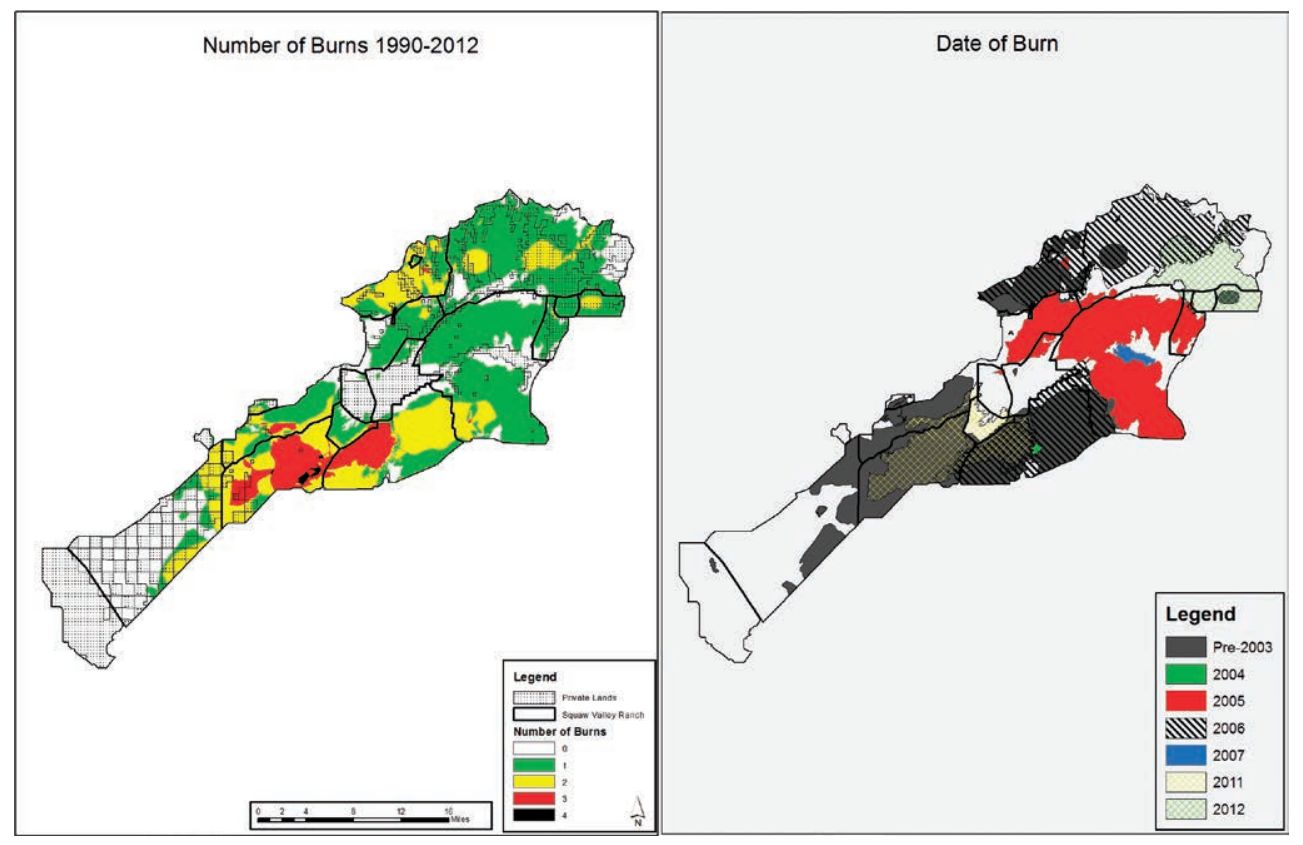

Figure 2. Burn history for Squaw Valley Ranch from 1990 to 2012 (left figure) and burned areas by year after 2003 (right figure).

sage grouse, ${ }^{1,5}$ and sagebrush fires are usually high-severity and stand-replacing, ${ }^{2}$ it is critical to the future viability of this species to reduce fire frequency and size while facilitating sagebrush reestablishment after fire.

\section{Fire}

Fires are the single biggest management challenge and the most significant threat to core sage grouse habitat on Squaw Valley Ranch. Since 1990, the number of fires on any particular piece of the ranch ranges from none to four (Fig. 2). Roughly 120,000 acres have not burned, while 150,000 acres have burned once, 75,000 acres have burned twice, 23,000 acres have burned three times, and just less than 1,000 acres have burned four times. Due to postfire grazing reductions or voluntary nonuse on federal grazing allotments, less than $20 \%$ of the total allowable AUMs, or 6,980 AUMs per year, were utilized between 2004 and 2008.

Although biomass or production data were not collected by the ranch, fire reoccurrence within nongrazed pastures suggests fine fuel accumulation or continuity may be a factor. This is a probable assumption for Squaw Valley Ranch, given that a northern Great Basin study reported significant increased fuel accumulations and continuity for ungrazed vs. grazed treatments. ${ }^{6}$ Results from that study also suggested moderate grazing can reduce the severity, continuity, and size of burns compared to ungrazed areas. ${ }^{6}$ On the ranch, all seven pastures that burned between 2004 and 2008 were rested 2 to 4 years prior to burning. Five of the seven fires during that time period occurred in 2006, following an extremely wet year in 2005 (18.3 inches precipitation). The fires occurring in 2012 were preceded by a wet year in 2010 ( 15.3 inches precipitation) and one or more years of rest from grazing. With few exceptions, fires on the ranch have been preceded by rest from grazing, especially when coupled with above average precipitation ( $>11.5$ inches). Areas on the ranch with higher rates of precipitation ( $>14$ inches) provide a good example for the rest-burn cycle. All five higher-precipitation pastures were rested in 2004 and 2005, with 2005 being an extremely wet year. In 2006, $90 \%$ of those five pastures or about 96,000 acres burned. Of the five pastures, one has been completely rested since 2006 and another since 2004 (did not burn in 2006 ) and both areas burned in 2012, following a wet year in 2010 and dry years in 2011 and 2012. The three higher-precipitation pastures that were grazed between 2010 and 2012 did not burn in 2012.

Similar to results from Balch et al. ${ }^{7}$ where, unlike native vegetation fires, cheatgrass fires showed a strong response to wet years, Open Range Consulting (unpublished data) indicated a positive correlation between fire size and the previous year's percentage of normal precipitation on Squaw Valley Ranch. This means that higher precipitation increases the probability of large fires the following year; regrettably, there is minimal flexibility to use more AUMs following a wet year for reduction of fuel loads on the federal grazing allotments. Since the invasion of cheatgrass into these communities changes the fuel structure, resulting in more frequent and less complex fires, ${ }^{8}$ we assume that fire frequency on the ranch may be influenced by the accumulation of fuels with rest from grazing. A factor impeding recovery of sage grouse habitat, frequent fires reduce the probability of sagebrush reestablishment in burned areas. For example, mountain big sagebrush (Artemisia tridentata subsp. vaseyana) can take 35-100 years to recover after fire and Wyoming big sagebrush (Artemisia tridentata subsp. wyomingensis) can take 50-120 or more years. ${ }^{2}$ Figure 3 illustrates an example of reduced sagebrush recovery after multiple fires on Squaw Valley Ranch. The left side of the road burned 


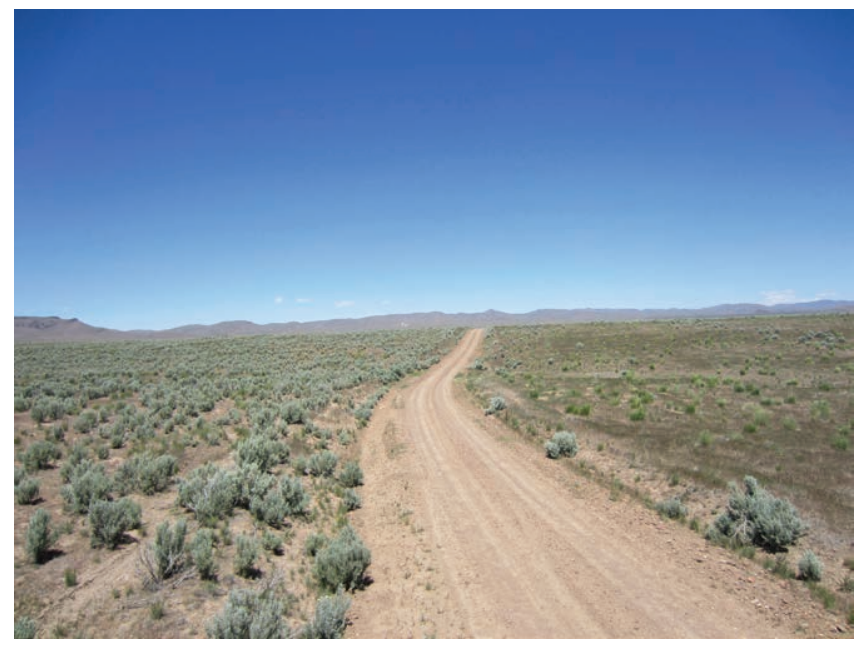

Figure 3. Left side of road burned in 2005 and has a healthy stand of sagebrush. The right side of the road burned in 2000 and again in 2005; it currently has very limited sagebrush reestablishment after 7 years and is dominated by perennial bunchgrasses and cheatgrass.

in 2005 and now has a healthy sagebrush community whereas the right side has burned in 2000 and 2005 and has had limited sagebrush establishment. Both sides of the road were seeded in 2006 and rested for four years postfire.

In areas where postfire seeding did not occur, sagebrush recruitment has been minimal after repeated burning. For example, two 100,000-acre fires occurred in 2001 and 2006, with $75 \%$ overlap in the burned area. Following the 2001 fire, burned pastures were rested from grazing and then burned again in 2006. According to the land cover assessments conducted by Open Range Consulting, the change in cover type after two fires within 5 years was from sagebrush-perennial grass communities to either perennial grass-dominated with above 10 inches of precipitation or cheatgrass-dominated with below 10 inches of precipitation. Although this conversion from shrublands to grasslands is beneficial for livestock grazing management, it is detrimental for sage grouse habitat due of the size of the burns and reduction in sagebrush cover.

Although there is some opposition to postfire grazing, some studies have shown that properly applied grazing management does not impede postfire recovery of perennial bunchgrasses or the herbaceous understory in sagebrush communities. ${ }^{9,10}$ Additionally, targeted cattle grazing can reduce cheatgrass biomass and cover, which reduces flame lengths and rate of spread in cheatgrass-invaded rangelands. ${ }^{11} \mathrm{Da}-$ vies and colleagues ${ }^{12}$ reported about $30 \mathrm{~kg} / \mathrm{ha}$ of cheatgrass in treatments grazed prior to burning whereas ungrazed and burned treatments had almost $300 \mathrm{~kg} / \mathrm{ha}$ cheatgrass, suggesting that grazing prior to fire may reduce the response of cheatgrass postburn. Using targeted grazing to reduce cheatgrass may be very beneficial to adjacent sagebrush-dominated communities because, as Balch et al. ${ }^{7}$ reported, fires that burned through multiple vegetation types were more likely to have started in cheatgrass. Since prior disturbances influence the response of plant communities to subsequent disturbanc- es, ${ }^{12}$ grazing before and after fire may have a cumulative effect in reducing cheatgrass and ultimately in reducing the risk of another fire within a short time period (i.e., burn-rest-burn). Together, these studies suggest that properly managed grazing can be beneficial to reduce the threat, extent, and severity of fire while not hindering postfire plant recovery.

The numerous fires have affected the overall management strategies of the ranch as well as the monetary resources. Fires on the ranch are expensive, with costs associated with reduced forage availability, fire suppression, and postfire seeding (over 70,000 acres) for the protection of soil resources and restoration of wildlife habitat. As a result of rest after fire on federally managed lands, over 120,000 AUMs have been forgone by the ranch since 2003 , a loss of about $\$ 1.8$ million. Other indirect costs include a lack of flexibility in the grazing plan due to the reduced number of grazeable pastures each year, which directly impacts cattle management (moving, trailing, fertility, etc.) on the ranch. Using costs per acre $(\$ 315-1,805)$ for different fire suppression strategies, ${ }^{13}$ estimates for the fires on the ranch since 1990 range from $\$ 100$ million to $\$ 673$ million. In addition to the monetary costs for fire suppression, the ranch has documented reduced use by sage grouse and mule deer populations postfire.

\section{Discussion}

Squaw Valley Ranch has successfully used adaptive grazing management over the last decade to improve rangeland condition and riparian function even though almost $70 \%$ of the ranch has burned at least once since 1990, with some areas burning as many as four times. Is it a coincidence that the pastures that burned had a prior absence of livestock grazing prescribed by the federal land management agency? We understand that there are differences between private land and public land, but when $14 \%$ of the federally managed lands with sagebrush-dominated communities as the potential remain unburned since 1990 , compared to $89 \%$ of the privately managed lands, there is the question of whether federal land management policies and practices may be increasing fire potential and size. Additionally, since fire influences the presence or dominance of cheatgrass and male sage grouse annual survival is less when breeding leks are impacted by invasive annual grasses, ${ }^{4}$ it is important to consider that large-scale wildfires may lead to an increased likelihood of sage grouse population declines.

The experience Squaw Valley Ranch has had with fire, livestock grazing, and sage grouse centers on management strategy and flexibility. Squaw Valley Ranch and the BLM Elko District have a monitoring program that allows for year-to-year adaptations of the grazing plan, as well as longterm planning for goals and assessment of goal achievement. The privately managed property has been grazed every year since 1999, and since 2003 has been grazed mostly during the dormant season at more than twice the stocking rate of the surrounding public land, and has only burned 415 acres or about $4 \%$ of the upland pasture acres since 1999 . On the 
other hand, the publically managed land has been grazed under permit regulations and has burned 85\% (232,320 acres) of the total acreage at least once. Squaw Valley Ranch has managed to keep fires to a minimum on their private ground by using livestock to reduce fuels and by doing land improvement projects, such as flanking existing roads with green-strip seedings, managing brush, seeding rangeland, and improving riparian habitat to function as green strips. This preventive and integrated ranch management program is working to reduce fire frequency and facilitate recovery of sage grouse habitat. The success of using preventive measures to suppress fires on the private lands of Squaw Valley Ranch provides a case study example for public land management and could be used to support the implementation of more preventive practices to reduce fire size in the Great Basin. This example demonstrates the wisdom of Ben Franklin's adage that "an ounce of prevention is worth a pound of cure." Although the regulations regarding vegetation management on private lands are far less restrictive than those on publically managed lands, perhaps a consideration of successful management strategies for reducing fire frequency may benefit far more than just sage grouse.

\section{References}

1. Nelle, P. J., K. P. Reese, And J. W. Connelly. 2000. Longterm effects of fire on sage grouse habitat. Journal of Range Management 53:586-591.

2. Baker, W. L. 2006. Fire and restoration of sagebrush ecosystems. Wildlife Society Bulletin 34:177-185.

3. Pedersen, E. K., J. W. Connelly, J. R. Hendrickson, and W. E. Grant. 2003. Effect of sheep grazing and fire on sage grouse populations in southeastern Idaho. Ecological Modelling 165:23-47.

4. Blomberg, E. J., J. S. Sedinger, M. T. Atamian, and D. V. Nonne. 2012. Characteristics of climate and landscape disturbance influence the dynamics of greater sage grouse populations. Ecosphere 3:art55.

5. Beck, J. L.,J. W. Connelly, And K. P. Reese. 2009. Recovery of greater sage grouse habitat features in Wyoming big sagebrush following prescribed fire. Restoration Ecology 17:393-403.
6. Davies, K. W., J. D. Bates, T. J. Svejcar, and C. S. Boyd. 2010. Effects of long-term livestock grazing on fuel characteristics in rangelands: an example from the sagebrush steppe. Rangeland Ecology E' Management. 63:662-669.

7. Balch, J. K., B. A. Bradley, C. M. D’Antonio, and J. GómezDANs. 2013. Introduced annual grass increases regional fire activity across the arid western USA (1980-2009). Global Change Biology 19:173-183.

8. Miller, R. F., S. T. Knick, D. A. Pyke, C. W. Meinke, S. E. Hanser, M. J. Wisdom, And A. L. Hild. 2011. Characteristics of sagebrush habitats and limitations to long-term conservation, In: S. T. Knick and J. W. Connelly [EDs.]. Greater sage grouse: ecology and conservation of a landscape species and its habitats. Studies in Avian Biology No. 38. Berkeley, CA, USA: University of California Press. p. 145-184.

9. Bruce, L. B., B. Perryman, K. Conley, and K. McAdoo. 2007. Case study: grazing management on seeded and unseeded post-fire public rangelands. The Professional Animal Scientist 23:285-290.

10. Bates, J. D., E. C. Rhodes, K. W. Davies, and R. Sharp. 2009. Postfire succession in big sagebrush steppe with livestock grazing. Rangeland Ecology \& Management 62:98-110.

11. Diamond, J. M., C. A. Call, and N. Devoe. 2009. Effects of targeted cattle grazing on fire behavior of cheatgrass-dominated rangeland in the northern Great Basin, USA. International Journal of Wildland Fire 18:944-950.

12. Davies, K. W., T. J. Svejcar, and J. D. Bates. 2009. Interaction of historical and nonhistorical disturbances maintains native plant communities. Ecological Applications 19:1536-1545.

13. Gebert, K. M., and A. E. Black. 2012. Effect of suppression strategies on federal wildland fire expenditures. Journal of Forestry 110:65-73.

Authors are Research Scientist (Freese) and Professor (Stringham, tstringham@cabnr.unr.edu), Dept of Agriculture, Nutrition and Veterinary Science, University of Nervada, Reno, 1664 North Virginia St, Mailstop 202, Reno, NV 89557, USA; and President (Simonds) and RSGIS Specialist (Sant), Open Range Consulting, Park City, UT 84098, USA. 